JERZY FLAGA* - LUBLIN

\title{
BRACTWA RELIGIJNE W EPOCE STAROPOLSKIEJ W ŚWIETLE ICH ORGANIZACJI I STRUKTURY WEWNECTRZNEJ
}

Przedmiotem artykułu jest zagadnienie struktury organizacyjnej wspólnot brackich oraz ich funkcjonowanie w ramach tej struktury w okresie staropolskim, dostrzegane $\mathrm{w}$ trakcie ich istnienia. Ważne jest to $\mathrm{z}$ tego względu, że bractwa prawie zawsze obejmowały swoim działaniem wszystkie odcinki życia religijnego i społecznego, a także wszystkie warstwy społeczne. Mówiąc o wspólnotach brackich mam na myśli zarówno bractwa, jak też arcybractwa, które niekiedy nosiły cechy konfraterni łączonych. Niektóre bowiem konfraternie - było to jedną $\mathrm{z}$ charakterystycznych cech organizacyjnych - posiadały tytuł arcybractwa, nadawany przez Stolicę Apostolską z przywilejem zakładania tego samego bractwa przy innych kościołach lub agregowania do swej brackiej wspólnoty istniejących już konfraterni o tej samej nazwie.

$\mathrm{Z}$ dotychczasowych badań poświęconych problematyce stowarzyszeń religijnych, jakimi były bractwa, zdaje się wynikać, że wymienione wyżej elementy występowały we wszystkich typach bractw niezależnie od czasu ich powstania i proweniencji kościelnej, tzn. czy były to wspólnoty istniejące przy kościołach parafialnych, czy też przy świątyniach zakonnych lub szpitalnych. W ujęciu generalnym wszystkie rodzaje form organizacyjnych i przejawy aktywności zdają się sprowadzać do podobnych praktyk, a jeśli nie podobnych, to na pewno bardzo do siebie zbliżonych ${ }^{1}$. Nie oznacza to bynajmniej, że się wcale nie różniły pod tym względem w obrębie poszczególnych kategorii konfraterni lub w ramach odpowiednich ich grup. $Z$ tych samych badań wiadomo również, że działalność odpowiednich typów bractw, w tym także ich struktura, były uzależnione od wielu czynników. Jednym z nich było to, z jakim zakonem były one związane, czyli jaki zakon je propagował i rozwijał. Innym - to, jakie obejmowały one warstwy spo-

* Jerzy Flaga - prof. historii; emerytowany pracownik KUL; e-mail: jurek.flaga@gmail.com

${ }^{1}$ J. Flaga, Bractwa religijne w Rzeczypospolitej w XVII i XVIII wieku, Lublin 2004, passim. Odwołuję się wyłącznie do własnej pracy, gdyż zawarta jest w niej bogata literatura, która w pełni potwierdza powyższe stwierdzenie. Por. także: W. Bielak, Księga bractwa Trójcy Przenajświętszej w parafii Dywin 1763-1800, „Archiwa, Biblioteki i Muzea Kościelne”, 98 (2012) s. 5-18. 
łeczne (szlachta, mieszczaństwo, wieśniacy), czy grupy społeczeństwa (młodzież ucząca się w kolegiach, wojsko); często znajdowało to swoje odzwierciedlenie w nazwach poszczególnych wspólnot. Kolejnymi czynnikami było związanie ich $\mathrm{z}$ odpowiednimi prawdami wiary (wspólnoty trynitarne, chrystologiczne, maryjne) lub świętymi oraz czas powstania bractwa (pojawienie się lub ożywienie w Kościele kultu odpowiedniej tajemnicy wiary, np. protestantyzm - wywołał ożywienie średniowiecznego bractwa Bożego Ciała; świeżo sprowadzony zakon bernardynów patronował i szerzył takie konfraternie jak: św. Anny (bardzo czczonej w zakonie), św. Franciszka Serafickiego (założyciela zakonu), Niepokalanego Poczęcia NMP (tajemnicy bronionej przez bernardynów) czy też bractwo żołnierskie pod wezwaniem św. Michała Archanioła (bernardyni często sprawowali funkcje kapelanów w wojsku), następnie kanonizacja w XVIII w. św. Jana Nepomucena przyczyniła się bardzo do upowszechnienia bractwa imienia tego świętego, itd. ${ }^{2}$

Mając to wszystko na uwadze postanowiłem przyjrzeć się bliżej dwóm ważnym zagadnieniom, które dotychczas pozostawały raczej na uboczu zainteresowań, tj. strukturze i organizacji wewnętrznej bractw i poddać je pełniejszemu oglądowi pod tym kątem ${ }^{3}$. Czynię to zgodnie z obserwowaną obecnie tendencją, w świetle której problematyka bracka, jest coraz częściej podejmowana i badana przez historyków, w tym zwłaszcza historyków Kościoła. Spowodowane jest to różnymi przyczynami, wśród których dwie zdają się dominować i wybijać. Pierwszą stanowi potrzeba nadrobienia zaległości z epoki poprzedniej, kiedy historiografia kościelna w ogóle, w tym także bracka była lekceważona, czy wręcz nie dopuszczana do głosu. Drugą zaś - obserwowana we wspomnianej już współczesnej historiografii - dążność do zajmowania się w badaniach i dociekaniach naukowych różnego typu wspólnotami, do jakich oczywiście bractwa są zaliczane. Na skutek obu owych tendencji właśnie w ostatnich latach badania nad bractwami poczyniły znaczne postępy; wyrazem tego jest ilość prac z tej dziedziny, ich liczba wyraźnie powiększyła się i systematycznie wzrasta.

Wyżej zaprezentowane podejście do tematu pozwoli, jak mniemam, dać odpowiedź na dwa podstawowe pytania. Po pierwsze skąd brały się wspomniane różnice lub podobieństwa, od czego były uzależnione, czy można je w jakiś sposób wytłumaczyć i usystematyzować. I drugie, może jeszcze bardziej ważne pytanie - jak można określić stopień organizacji wspólnot brackich, czy można je zaliczyć do instytucji o dobrej, czy mówiąc inaczej - wysokiej strukturze organizacyjnej. W oparciu o te dane można będzie starać się uzyskać odpowiedź na kolejne ważne pytanie, jakie stawia sobie współczesna historiografia dotycząca stowarzyszeń religijnych, w jaki sposób przebiegało funkcjonowanie wspólnot brackich w różnych okresach czasowych na przestrzeni historii.

${ }^{2}$ Tamże; J Flaga, Stowarzyszenia i bractwa religijne przy kościołach bernardyńskich do końca XVIII wieku, w: Pięćset pięćdziesiąt lat obecności OO. Bernardynów w Polsce (1453-2003), red. Wiesław F. Murawiec OFM, Damian A. Muskus OFM, Kalwaria Zebrzydowska 2006, s. 545-562.

${ }^{3}$ Są to dwa zagadnienia tylko od strony formalnej, merytorycznie jest to jedno zagadnienie o dużym ładunku badawczym i naukowym. 
Przy omawianiu interesującego nas tu zagadnienia, pod uwagę wzięte zostaną dwa przejawy konstytuujące bractwa, które należały do najbardziej zauważalnych i charakterystycznych, czy mówiąc inaczej - do najbardziej typowych. Stanowiły je: kształt struktury organizacyjnej i wypływające $z$ niej szeroko rozumiane obowiązki członków, a konkretnie władz bractwa. One decydowały o wykonywanych przez nie praktykach pobożnych i przywilejach przyznawanych bractwom przez instytucje kościelne ze Stolicą Apostolską włącznie. Należy też zaznaczyć, że wzięte pod uwagę owe dwa przejawy, tzn. formy struktury i obowiązki, były nie tylko zauważalne, ale bardzo powszechne (przez to były właśnie zauważalne), występowały bowiem we wszystkich wspólnotach brackich niezależnie od ich wielkości i miejsca założenia. Oczywiście, oprócz struktury i obowiązków związanych z działalnością, można wymienić cały szereg innych elementów i aktów konstytuujących instytucję wspólnot brackich, jak na przykład konkretne powinności członków, sposoby wpisywania do wspólnoty lub wydalania z niej (co miało miejsce zwłaszcza w sodalicjach), praktyki dewocyjne i spełniane dzieła miłosierdzia czy wreszcie też nadawane odpusty i przywileje ${ }^{4}$. Na marginesie można nadmienić, że niekiedy przyznane przywileje i odpusty znajdowały swoje odbicie w konstytucjach zakonnych, jak miało to miejsce w przypadku wspólnoty paulińskiej, co przenosiło się na bractwa ${ }^{5}$. Pomijam tutaj wszystkie akty mniej lub bardziej formalne, gdyż są one bardziej szczegółowe, niektóre z nich zawierają się w obu poprzednich, po trzecie uwzględnienie ich czyniłoby rozważania mniej przejrzyste i czytelne, nie mówiąc już o ograniczonych rozmiarach artykułu.

Jako materiał merytoryczny do rozważań zostaną wybrane pewne przykłady spośród bractw bardziej reprezentatywnych. Zwrócona będzie też uwaga na to, aby owe bractwa posiadały interesujące nas tutaj informacje. Posługuję się tylko przykładami, gdyż w rozważaniach o określonej objętości, trudno uwzględniać wszystkie konfraternie, których, jak wiadomo, liczba nie jest mała. Wyjaśnić trzeba też, że jako pierwsze po kształcie struktury omawiane będą obowiązki. Aczkolwiek praktyki dewocyjne również należały do obowiązków, jednakże pojęcie obowiązki jest nieco szersze od terminu praktyki, kryje się pod nim szereg innych przejawów aktywności. Łączne przyjrzenie się wszystkim owym przejawom aktywności bractw ma ten ważny walor, że pozwoli spojrzeć całościowo na ich funkcjonowanie, a w konsekwencji na rolę, jaką bractwa spełniały w społeczeństwie. W ten sposób będzie wypełniony postulat współczesnej nauki historycznej zachęcającej do badania małych grup, czy mówiąc inaczej - małych społeczności. Nie ulega bowiem wątpliwości, że w dawnej Rzeczypospolitej, obok parafii, szkół, kolegiów (te ostatnie tkwiły w strukturze zakonnej) i związków cechowych, były stowarzyszenia religijne, a w ich ramach wspólnoty brackie.

${ }^{4}$ Ks. W. Bielak w przywołanym artykule pisze co następuje: „Jak wynika z prezentowanych w księdze odpustów i powinności członków, Bractwo Trójcy Przenajświętszej miało przede wszystkim dewocyjny charakter ukierunkowany na oddawanie czci Trójcy Świętej poprzez udział w specjalnych nabożeństwach i modlitwę indywidualną" (Księga bractwa Trójcy Przenajświętszej w parafii Dywin 1763-1800, s. 5).

${ }^{5}$ F. Pasternak, Historia kodyfikacji konstytucji zakonu paulinów od 1308 do 1930 r., „Nasza Przeszłość”, 31 (1969) s. 11-74. 
Jednym z ważniejszych przejawów aktywności bractw było wykonywanie obowiązków, do jakich - jak już nadmieniłem - byli, obok „zwykłych” członków, zobowiązani zwłaszcza urzędnicy wchodzący w skład zarządów, którzy występowali we wszystkich wspólnotach brackich. Od nich więc wypada rozpocząć przedstawienie zapowiedzianych cech organizacyjnych i właściwości przynależnych poszczególnym rodzajom bractw. Podstawowym obowiązkiem, w połowie tylko o charakterze dewocyjnym, spoczywającym na członkach wszystkich wspólnot brackich było uczestnictwo w zebraniach brackich tzw. schadzkach zwanych niekiedy sesjami oraz wykonywanie zadań z tym związanych. Organizowaniem tego typu schadzek czy sesji zajmowały się zarządy bractw, które składały się - jak było nadmienione - $\mathrm{z}$ odpowiednich urzędników, w różnej liczbie w zależności od typu wspólnoty i różnie nazywanych w poszczególnych rodzajach bractw. W skład zarządu wchodziły z reguły osoby świeckie, jedynie promotorzy i w niektórych wspólnotach starszy bractwa były osobami duchownymi. Promotor nie był członkiem zarządu, czuwał natomiast nad całym bractwem, zwłaszcza w sprawach duchowych. W świetle dotychczasowych badań, w XVI-XVIII wieku wszystkie rodzaje bractw, od najbardziej rozpowszechnionych i zarazem najbardziej reprezentatywnych dwu konfraterni maryjnych: różańcowych i szkaplerznych poczynając, poprzez wspólnoty poświęcone poszczególnym świętym, na bractwach rolników, ubogich i miłosierdzia kończąc, posiadały tego typu urzędników. Można powiedzieć, że nie było wspólnoty brackiej, która nie posiadałaby odpowiedniego zarządu. Podobną strukturę miały też sodalicje studenckie, jakie istniały przy kolegiach jezuickich i pijarskich. Pomijając obowiązki promotora, którym - jak zaznaczyłem - był duchowny, przyjrzymy się w miarę możliwości obowiązkom pozostałych członków zarządu. Zarządy były mniej lub bardziej rozbudowane, tzn. posiadały odpowiednią liczbę oficjalistów, jak ich wówczas najczęściej nazywano. Zarząd poszczególnych bractw przeważnie wybierali jego członkowie w czasie zebrań organizowanych specjalnie w tym celu. Na przykład w powołanym pod koniec XVI w. przez Piotra Skargę, jezuickim bractwie miłosierdzia, zarząd wybierano podczas zebrania $\mathrm{w}$ głosowaniu pośrednim przez siedmiu elektorów, przy czym w zebraniu mogli uczestniczyć wyłącznie mężczyźni. Zarząd ten był wybierany na rok i podlegał kontroli ogółu członków bractwa. Na czele tak wybranego zarządu stał starszy, którym do XVIII wieku był duchowny. Starszego wspomagali odpowiedni urzędnicy braccy, a więc radni, pisarz, szafarz i wizytatorzy. Funkcjonariusze ci mieli spełniać swoje obowiązki zgodnie z przypisanymi im funkcjami wyrażonymi w ich nazwie. Ponadto bractwo posiadało opiekuna i doradcę, którym był patron, oraz kapelana i ojca duchowego ${ }^{6}$.

Podobnie, jeśli nie całkowicie, to w dużej mierze, była formowana struktura i obowiązki we wznowionym ponownie w XVIII w. bractwie przez, najpierw biskupa płockiego, następnie prymasa Michała Jerzego Poniatowskiego. Obowiązki jego określone były przez odpowiednie statuty. W myśl owych statutów wypeł-

${ }^{6}$ Encyklopedia wiedzy o jezuitach na ziemiach Polski i Litwy, oprac. L. Grzebień, Kraków 1996, s. 62. 
nianie obowiązków było dobrowolne i nie było nałożone pod grzechem ciężkim. Członkowie byli zobowiązani wypełniać je od momentu przyjęcia i wpisania do wspólnoty, gdyż zaznajamianie się z nimi odbywało się jeszcze przed przyjęciem do bractwa. W celu utrwalenia ich znajomości czytano je na schadzkach, na których kapłan lub członek zarządu objaśniali je w razie potrzeby ${ }^{7}$.

A oto jak kształtowały się obowiązki w bractwie literackim nauki chrześcijańskiej w Nowym Sączu. Bezpośrednim i właściwym kierownikiem w tej wspólnocie był zwykle kapłan, zwany, podobnie jak w bractwie miłosierdzia, ojcem duchownym. Do obowiązków jego należało czuwać nad wszystkimi sprawami natury dewocyjnej, takimi jak: wypełnianie przez członków właściwych im obowiązków, przewodniczenie na posiedzeniach bractwa, oraz sprawowanie pieczy nad kancelarią i biblioteką wspólnoty. Ojciec duchowny wspierany był przez starszych bractwa w liczbie czterech, którzy rekrutowali się spośród świeckich członków wspólnoty. Tutaj należy przywołać interesującą uwagę, że przynajmniej połowa z nich wywodziła się z miejskiej ławy radzieckiej. Ich zgoda była wymagana do przeprowadzenia ewentualnych zmian w statucie i zwyczajach bractwa. Starsi bractwa czuwali także nad ofiarami składanymi na rzecz wspólnoty. Kolejnym urzędnikiem był pisarz bracki, mógł nim być zarówno duchowny, jak i osoba świecka. Prowadził on pod okiem ojca duchownego sprawy kancelaryjne bractw ${ }^{8}$. Następnym urzędnikiem był szafarz, była nim z reguły osoba świecka. Zajmował się sprawami gospodarczymi, gdyż bractwo posiadało własne pieniądze. Pochodziły one z obowiązkowych ofiar, składanych przez członków przy okazji przyjęcia do wspólnoty lub w czasie zebrań kwartalnych. W skrzynkach, oprócz pieniędzy, przechowywano również dokumenty brackie. Wyłącznie osobą świecką był kolejny oficjalista - sługa bracki, który spełniał posługi wobec współczłonków w czasie nabożeństw brackich. Zgodnie ze statutem funkcję te powierzano dzwonnikowi kolegiaty. Ostatnią grupę urzędników w bractwie stanowili tzw. wizytatorowi. Wykonywali oni szereg prac charytatywno-społecznych, a więc odwiedzali i opiekowali się chorymi, odwiedzali więźniów, zajmowali się rozdzielaniem i roznoszeniem dóbr materialnych, godzeniem osób zwaśnionych, zachęcali także i przygotowywali do sakramentów świętych. Wszyscy urzędnicy pochodzili $\mathrm{z}$ wyboru, a kadencja ich trwała rok. W przypadku nowych wyborów członkowie dotychczasowego zarządu mogli ponownie kandydować. Zebranie wyborcze połączone było z ceremonią religijną, sprawowaną przeważnie przez ojca duchownego. Działalność bractwa, zarówno wewnętrzna, jak i zewnętrzna, podlegała kontroli ze strony wszystkich jego członków na wspólnym posiedzeniu, zwanym liczby czynienie. Pozostałe wspólne zebrania bractwa, zwane schadzkami, organizowano raz na kwartał oraz przed świętem Zwiastowania NMP. Wówczas urzędnicy przedkładali wobec wszystkich członków bractwa sprawozdanie z powierzo-

${ }^{7}$ M.J. Poniatowski, Ustanowienie bractwa mitosierdzia po parafiach dyecezyi plockiey, Warszawa 1777; tenże, Ustanowienie bractwa miłosierdzia po parafiach archi-dyecezyi gnieźnieńskiey, Łowicz 1786; J. Czyż, Bractwa milosierdzia w II połowie XVIII wieku w świetle statutów i wybranych źródet, Lublin 1988 (mps w Archiwum KUL).

${ }^{8}$ Statuty Bractwa Literackiego Nauki Chrześcijańskiej przy kolegiacie św. Matgorzaty w Nowym Saczu, wyd. B. Kumor, „Archiwa, Biblioteki i Muzea Kościelne”, 2 (1961) z. 1-2, s. 357-370. 
nych im obowiązków i wykonanych czynności. Przy okazji zebrań kwartalnych członkowie wspólnoty składali obowiązkowo odpowiednie ofiary, tzw. oferty9.

W bardzo zbliżony sposób do konfraterni w Nowym Sączu kształtowały się struktura wewnętrzna i obowiązki w bractwie literackim w Koprzywnicy. Podobnie jego władze dzieliły się na urzędników starszych i młodszych. Do starszych należeli seniorzy i wiceseniorzy, a w pewnym okresie prefekci i skarbnicy. Grupe pośrednią stanowili konsulatorzy i prokuratorzy, spośród których dopełniano skład zarządu. Wraz z seniorami i skarbnikami wykonywali oni rozmaite funkcje, jak np. świadków przy transakcjach finansowych. Zdaniem H. Rucińskiego wpływ na osiągnięcie wyższych godności w bractwie miał nie tyle staż czy wiek, ile raczej pozycja lub stanowisko kandydata w lokalnej społeczności. Według tego autora, wspólną cechą, jaka łączyła bractwa literackie, było ich powiązanie z władzami miejskimi. Było to spowodowane tym, że uczestnictwo w bractwie literackim wymagało pewnego wykształcenia, które brano pod uwagę także przy powoływaniu na urzędy miejskie ${ }^{10}$. Fakt powyższy potwierdza również znany pamiętnikarz Jędrzej Kitowicz, który odnosząc się do bractwa literackiego tak m.in. pisze:

Że tedy umieli czytać, a co większa po łacinie, choć wielu z nich tego języka nie rozumieli, stąd bractwo swoje nazywali literackim, a siebie literatami, lubo i to prawda, że wielu z nich byli ludźmi uczonymi osób magistratowych ${ }^{11}$.

Bardzo zbliżone urzędy występowały również w zreformowanym na początku XVII wieku bractwie św. Urszuli w Krakowie. Konfraternia ta miała swojego protektora, ojca duchownego oraz starszych bractwa, do których zaliczali się seniorzy, radni i pisarz. Seniorzy załatwiali sprawy związane z majątkiem bractwa, dokonywali aktów kupna, sprzedaży, przeniesienia czynszu, ubezpieczenia sum oraz dochodzili zaległego czynszu, innymi słowy zabiegali o dochody bractwa. W XVIII wieku seniorami były znaczniejsze osobistości, jak wójt czy ławnicy z poszczególnych przedmieść Krakowa. Nie zawsze było to z korzyścią dla bractwa, gdyż obciążeni funkcjami publicznymi nie spełniali w sposób należyty lub w ogóle swoich obowiązków. Dodatkowo seniorzy piastowali pewne urzędy (zwykle nieco niższe) w konfraterni szkaplerznej u karmelitów na Piasku ${ }^{12}$. Wszyscy urzędnicy byli wybierani na specjalnych zebraniach, w czasie których przyjmowano także nowych członków do wspólnoty. Po wpisaniu do albumu nowo przyjęty brat, trzymając zapaloną świecę, odmawiał głośno przed ołtarzem św. Urszuli - wobec ojca duchownego, seniora lub sekretarza - przepisaną modlitwę. Po jej

\footnotetext{
${ }^{9}$ Tamże, s. 357-388.
}

${ }^{10}$ Przykładem może być bractwo koprzywnickie, w którym wśród seniorów zawsze znajdowali się przedstawiciele władz miejskich (H. Ruciński, Bractwo literackie w Koprzywnicy jako obraz struktury społecznej miasteczka w latach 1694-1795, „Przegląd Historyczny”, 65 (1974) z. 2, s. 270-272).

${ }^{11}$ J. Kitowicz, Opis obyczajów za panowania Augusta III, oprac. Roman Pollak, wyd. 3, Wroclaw 1970, s. 23.

${ }^{12}$ Przykładem tego jest Jan Gielhorn, starszy bractwa w latach 1722-1748, który był wójtem Garbar i równocześnie - w latach 1723-1732 pełnił funkcję podskarbiego w konfraterni szkaplerznej (Flaga, Bractwa religijne w Rzeczypospolitej w XVII i XVIII wieku, s. 69). 
ukończeniu obecni na ceremonii bracia witali nowego członka ${ }^{13}$.

Kontynuując rozważanie spróbujmy obecnie przyjrzeć się strukturze i obowiązkom bractw szkaplerznych. Otóż w przypadku bractw funkcjonujących przy klasztorach całkowita pieczę nad nimi miał przeor konwentu. Obok przeora, innym bezpośrednim kierownikiem ze strony zakonu był jeden z ojców, wybrany na kapitule prowincjalnej lub konwentualnej, nazwany prezydentem, dyrektorem lub po prostu promotorem. Promotor miał czuwać nad zachowaniem ustaw brackich; posiadał on również pieczęć bracką i jeden klucz od kasy ${ }^{14}$. Poza zakonem bractwo mogło mieć swoich protektorów i protektorki, do których należały bądź to osoby duchowne, bądź świeckie, zajmujące niekiedy wysokie stanowiska w hierarchii społecznej. Wspólnota ta posiadała zarząd, który obejmował urzędy wyższe, odnoszące się do kierownictwa konfraternią i funkcjonariuszy niższych, którzy wykonywali różne posługi brackie oraz czynności nieprzewidziane. Do wyższych należały urzędy: przeora, zastępcy przeora, zwanego podprzeorem lub wiceprefektem, i siedmiu radnych, zwanych konsulami ${ }^{15}$. Wśród tych ostatnich dwóch pełniło funkcję arbitrów. Ponadto byli jeszcze: skarbnik, zwany podskarbim, pisarz lub sekretarz oraz zakrystian. Bardzo interesująco przedstawiały się obowiązki przeora. Zapisano na ten temat:

Do pana przeora należały: decyzje w rozmaitych sprawach, poważnych $\mathrm{w}$ porozumieniu z przeorem, w małych - podejmowane samemu z konsyliarzami i promotorem; ogłaszanie posiedzeń brackich i dopilnowanie obecności urzędników; czuwanie nad wypełnianiem wszystkich zadań; troska o uczciwość członków i ich szacunek dla przeora; upoważnienie do powoływania i odwoływania urzędników; prawo do posiadania jednego klucza od skarbca brackiego i kontroli nad podskarbim oraz obowiązek przypominania kaznodziei o zachęcaniu do bractwa.

W drugiej połowie XVII wieku przeor miał także prawo do posiadania pieczęci brackiej, kontroli ksiąg inwentarzowych, wizytowania dóbr ruchomych i nieruchomych. Podprzeor w roli zastępczej cieszył się pełnymi uprawnieniami przeora. Troszczył się m.in. o spowiednika dla członków, wyznaczonego przez kapitułę prowincjonalną lub konwentualną, przeprowadzał wespół z przeorem wizytację

${ }^{13}$ M.K. Ryk, Bractwo św. Urszuli w Krakowie, Lublin 1961, mps, s. 16-19a, 27, 81. W początkowym okresie przyjęcie nowych członków odbywało się bardzo prosto. Kandydat wyrażał zgodę na przystąpienie do bractwa, pisarz umieszczał jego imię i nazwisko w księdze brackiej (albumie), a wszyscy obecni witali nowych członków uściskiem dłoni. Przy tej okazji zaznajamiali się z obowiązkami bractwa i składali odpowiednią ofiarę pieniężną do skrzynki brackiej. W XVIII w. przyjęcie do bractwa było połączone już z pewną ceremonią. Osoba chcąca należeć do bractwa, udawała się przed ołtarz św. Urszuli, tam oddawała się w niewolnictwo świętym dziewicom, aby uprosić sobie ich pomoc we wszystkich potrzebach, a zwłaszcza w godzinę śmierci. Potem następowało oficjalne przyjęcie do bractwa.

${ }^{14}$ W.J. Benignus, Zakon karmelitów bosych w Polsce. Klasztory karmelitów i karmelitanek bosych, Kraków 1979, s. 723-724; B. Panek, Dzieje bractwa Szkaplerza świętego przy kościele OO. Karmelitów w Krakowie na Piasku do końca XVII wieku, „Roczniki Teologiczno-Kanoniczne”, 10 (1963) z. 3, s. 50.

${ }^{15}$ Wanat, Zakon karmelitów bosych, s. 724, Według Panka, Dzieje bractwa szkaplerza, s. 51, było ośmiu rektorów, prawdopodobnie chodzi o ten sam urząd, tylko inaczej nazwany. 
roczną i pilnował ogólnego porządku we wspólnocie, posiadał drugi klucz od skarbca. Konsyliarze w czasie nieobecności przeora i podprzeora mieli prawo ich zastępować, jednakże podejmowane decyzje musieli uzgadniać $\mathrm{z}$ władzami klasztoru. Ich szczególnym zadaniem była troska o ofiary na rzecz bractwa. Wszelkiego typu nieporozumienia wśród członków mieli rozstrzygać arbitrzy, którzy winni odznaczać się spokojem, opanowaniem i dużym wyrobieniem duchowym. Do obowiązków skarbnika należało przyjmowanie ofiar i składek brackich oraz prowadzenie listy ofiarodawców, księgi dochodów i rozchodów. Miał także troszczyć się o świece do mszy św. brackich oraz o aparat do brackiego ołtarza lub kaplicy. Bardzo odpowiedzialny był urząd pisarza. Miał on składać przysięgę, że będzie pisał zgodnie z prawdą, on bowiem prowadził księgi praw i księgi protokołów zebrań brackich. W przypadku jego nieobecności zastępował go jeden z konsyliarzy, przekazując mu następnie protokoły ${ }^{16}$. Liczne obowiązki spoczywały również na urzędnikach niższych. Na przykład zakrystian miał troszczyć się o sprzęty kościelne, o ład i porządek w kościele, opiekować się ołtarzem i kaplicą konfraterni, a także czuwać nad naczyniami i szatami liturgicznymi. Dodatkowo do niego należało przygotowanie stołu do udzielania komunii św. w domu chorego, spisywanie na kartkach mszy św. i dopilnowanie, aby były one odprawione. On miał też zajmować się sporządzaniem inwentarza rzeczy kościelnych (w dwóch egzemplarzach: jeden dla siebie, drugi do przechowania w skrzyni brackiej) i przekazywaniem jałmużny podskarbiemu. Oprócz zakrystiana, do niższych urzędników zaliczali się: prokuratorzy ołtarza, prowizorzy, chorążowie, jałmużnicy, marszałkowie, infirmarze - jak widzimy był to zespół bardzo rozbudowany. Wszystkie wymienione urzędy powierzano członkom bractwa ${ }^{17}$. Liczba ich prawdopodobnie nie była stała i ulegała zmianom. W bractwie krakowskim np. było dwóch prokuratorów, trzech prowizorów, dwóch chorążych wraz z czterema pomocnikami, dwóch jałmużników, sześciu marszałków, czterech do noszenia obrazów, dwóch sług i dwóch infirmierzy. Funkcje prokuratorów ołtarza podobne były do obowiązków zakrystiana. Mieli opiekować się kapami brackimi i sprawować kontrolę nad zakrystianem. Do zadań prowizorów spraw świeckich należało załatwianie wszystkich spraw brackich na zewnątrz, mieli także świadczyć pomoc członkom wspólnoty we wszelkich sprawach sądowych. Kandydaci do tego urzędu mieli znać prawo cywilne i kościelne oraz cieszyć się poważaniem wśród wiernych. Chorążowie i ich pomocnicy mieli opiekować się krzyżem, chorągwiami i laskami brackimi oraz nosić je na procesjach. Za porządek na procesjach byli odpowiedzialni marszałkowie. Czynili to za pomocą lasek, którymi torowali drogę wśród licznie zgromadzonych wiernych. Dwóch jałmużników ubranych w kapy miało zajmować się zbieraniem jałmużny dla bractwa przed drzwiami kościoła. Słudzy braccy mieli pełnić obowiązek posłańców powiadamiających o zebraniach, procesjach lub śmierci któregoś z członków. W czasie sesji brackiej mieli pozostawać do dyspozycji starszych, pozostając przy wejściu do sali. Za posługi otrzymywali odpowiednie wynagrodzenie. Infirmarze, podobnie jak we wszystkich konfraterniach, mieli troszczyć się o chorych, niosąc im potrzebną pomoc ${ }^{18}$.

\footnotetext{
${ }^{16}$ Panek, Dzieje bractwa szkaplerza, s. 53.

${ }^{17}$ Wanat, Zakon karmelitów bosych, s. 724; Panek, Dzieje bractwa szkaplerza, s. 53-54.

${ }^{18}$ Tamże.
} 
Podobne urzędy miały również członkinie należące do społeczności brackiej. Spośród pań starszych, tzw. oficjałek, wybierano przeoryszę, podprzeoryszę, podskarbinę, zakrystiankę i osoby do nawiedzania chorych; tak przynajmniej było w bractwie krakowskim ${ }^{19}$. Wybory całego zarządu bractwa organizowano każdego roku na sesji nadzwyczajnej. W drugą lub trzecią niedzielę miesiąca organizowano zebranie konfraterni z nabożeństwem i szkaplerzną procesją. Wiadomo, że wspólnota krakowska posiadała określone dni wyborów - dla braci był to 16 lipca, czyli uroczystość MB Szkaplerznej, dla sióstr -8 grudnia, tj. święto Niepokalanego Poczęcia NMP ${ }^{20}$. W bractwie krakowskim przy wyborach byli obecni także przeor konwentu, prezydent, często też goście, jak biskup i radni miejscy. Wyboru dokonywano większością głosów, a wyniki protokołowano. Urzędy pełniono tylko przez rok, tak przynajmniej było w XVII wieku. Każdy nowo wybrany zarząd napominano, aby czuwał nad sprawnym i prawidłowym funkcjonowaniem bractwa. Jak wynika z dotychczasowych badań, polecenie to było przestrzegane, przynajmniej w przypadku bractwa krakowskiego w XVIII wieku. Potwierdzają to akta wizytacji kurii krakowskiej z pierwszej połowy XVIII w., w których stwierdzono, że w minionym stuleciu funkcjonowanie organizacji bractwa szkaplerza św. w Krakowie na Piasku było prawidłowe, tak w sprawach duchowych, jak i administracyjnych ${ }^{21}$. Powyższą ocenę dokumentują również regularnie i porządnie prowadzone księgi tego bractwa ${ }^{22}$. Zdaje się nie ulegać wątpliwości, że duży wpływ na wymienione poprawne funkcjonowanie bractwa miało dokładne określenie wszystkich zadań i obowiązków poszczególnych oficjalistów, o których była wcześniej mowa.

W interesujący i godny zauważenia sposób kształtowała się struktura organizacyjna w bractwach różańcowych. W początkowym okresie administracja konfraterni różańcowych była bardzo prosta. Zarząd pierwszego bractwa założonego we Wrocławiu w 1481 r. na pewno tworzyli: dwaj stróże, którymi byli burmistrz miasta i jeden ze znaczniejszych mieszczan, oraz prawdopodobnie prokurator bractwa, którego miał wybierać proboszcz. Do obowiązków stróżów należało kierownictwo administracyjne bractwa, prokuratorowi zaś podlegały sprawy majątkowe. Dopiero w miarę upływu czasu powstawały nowe urzędy. Przybywało ich tak wiele, że z końcem XVI wieku było ich już 15, na wzór 15 tajemnic różańcowych ${ }^{23}$. W końcowych latach XV wieku owe 15 urzędów dzieliły się na urzędy wyższe i niższe, zwane w statucie ,podlejsze”. Urzędnikami kategorii wyższej byli: przeor, jego zastępca (podprzeor), 8 konserwatorów, prowizor ołtarza, podskarbi, dwóch prokuratorów i pisarz. Do kategorii urzędów niższych zaliczano: dwóch zakrystianów, dwóch chorążych, jałmużnika, czterech pomocników, marszałków (w zależności od potrzeby), oraz oficjalistów zwanych sługami (powoływanych stosownie do potrzeby). W przeciwieństwie do pierwszych nie przysługiwały im miejsca honorowe $\mathrm{w}$ bractwie i spełniali $\mathrm{w}$ nim proste po-

\footnotetext{
${ }^{19}$ Panek, Dzieje bractwa szkaplerza, s. 51-54.

${ }^{20}$ Wanat, Zakon karmelitów bosych, s. 723-724.

${ }^{21}$ Flaga, Bractwa religijne, s. 73 .

22 Panek, Dzieje bractwa szkaplerza, s. 51-52.

${ }^{23}$ Piróg, Geneza i rozwój bractw, s. 39.
} 
sługi ${ }^{24}$. Ten rozbudowany system urzędów był, można powiedzieć, trwały. Ulegał wprawdzie różnym zmianom, ale zachował swoją moc i przetrwał do wieku XIX. Na przykład zarząd Arcybractwa Różańcowego wprowadzonego w 2. połowie XIX w. do kościoła Franciszkanów-Reformatów we Włocławku tworzyli: ksiądz promotor, czterej protektorowie oraz pięciu urzędników, mianowicie: starszy brat, podskarbi, dwóch asesorów i bracki. Odnotować należy też dwie ważne informacje dotyczące wzajemnych relacji w bractwie. Przytoczę je tutaj szczegółowo, gdyż obrazują one funkcjonowanie konfraterni przyklasztornej, które wynikało z jej struktury, jaka jest przedmiotem rozważań. Pierwsza informacja sprowadza się do tego, że zalecano, aby przy doborze kandydatów nie kierowano się osobistymi widokami i względami, ani nie słuchano namów. Pod uwagę należało brać jedynie chwałę Boga i dobro ogółu arcybractwa. Po wyborze natomiast, zgodnie z zaleceniem ks. promotora, członkowie wspólnoty powinni okazywać uszanowanie i posłuszeństwo członkom zarządu. Druga informacja bardziej obszerna dotyczyła przejawów funkcjonowania bractwa. W jej myśl urzędnicy, zgodnie z Ustawa, mieli wspólnie z przełożonym miejscowym i promotorem udzielać dobrych rad w celu dokonania ulepszeń potrzebnych w bractwie i przedstawiania wniosków na posiedzeniach. Na sesjach kwartalnych mieli sprawdzać księgi rachunkowe, przeliczać pieniądze w kasie, czuwać nad tym, aby wydatki nie były większe od przychodów. Oprócz spraw finansowych mieli nadto interesować się sposobem prowadzenia się członków arcybractwa oraz otaczać opieką chorych, zwłaszcza ubogich, którzy wymagali pomocy. Mieli także czuwać, aby nikt z chorych członków nie umarł bez sakramentów św. Oni też jako bardziej wykształceni mieli dobierać i zaopatrywać członków konfraterni w odpowiednią literaturę, z której powinni korzystać umiejący czytaće ${ }^{25}$.

\section{Podsumowanie}

W świetle zaprezentowanych rozważań śmiało można powiedzieć, że ustrój i struktura wewnętrzna bractw w XVI-XVIII wieku była na ogół bardzo rozwinięta, Jeśli nie wszystkie, to wiele wspólnot posiadało własne statuty. W przypadku np. XVIII-wiecznego bractwa miłosierdzia autorem ich był sam biskup. Zapewne były one drukowane, gdyż wiadomo, że bractwa przechowywały dokumenty, nawet gdy nie dysponowały specjalnym pomieszczeniem archiwalnym. Wykorzystywały wówczas w tym celu, jak to miało miejsce w bractwie literackim w Nowym Sączy, skrzynki brackie przeznaczone do zbierania pieniędzy. To oznacza, że przywiązywano do tych dokumentów dużą wagę, czyli bractwa miały właściwe zrozumienie dla dokumentów i pełną świadomość ich znaczenia. Zapewne było to wyrazem ówczesnego sposobu podchodzenia do dokumentów. Czyniły tak wówczas wszystkie instytucje, chodziło w nich przede wszystkim o zabezpieczenie

${ }^{24}$ Bzowski, Różaniec Panny Maryjej teraz nowo w Krakowie Ś. Trójcy reformowany, Kraków 1600, cz. 4, s.

${ }^{25}$ J. Flaga, Arcybractwo Różańcowe przy kościele Franciszkanów-Reformatów we Włoctawku, w: Non cesso gratias agere Deo et hominibus. Prace ofiarowane Ojcu dr Anzelmowi Januszowi Szteinke OFM z okazji Złotego Jubileuszu Kapłaństwa i ponad 50-lecia pracy historyczno-pisarskiej, red. W.M. Michalczy OFM, C.M. Paczkowski OFM, Kraków-Warszawa 2013, s. 488. 
spraw majątkowych i finansowych. Tym niemniej w przypadku bractw, w których sprawy finansowe były na dalszym planie, jest to godne zauważenia. Należy też przypomnieć, że na przykład w bractwach literackich przy powoływaniu na urzędników wymagano odpowiedniego wykształcenia. Fakty te pokazują, że konfraternie posiadały znajomość form organizacyjnych ówczesnego życia społecznego od strony administracyjnej i prawnej i w miarę możliwości realizowały je u siebie. Dowodzi tego też fakt spisywania praw i protokołów z posiedzeń brackich, czym zajmował się pisarz, który w niektórych bractwach był zobowiązany składać przysięgę, że będzie pisał zgodnie z prawdą. Jest to kolejny dowód, że formy organizacji bractw były, jeśli nie doskonałe, to na pewno poprawne, zgodne $\mathrm{z}$ normami. Było to możliwe, gdyż - można przyjąc $\mathrm{z}$ dużym prawdopodobieństwem - czuwali nad tym zarówno sami członkowie wspólnot poprzez własne zarządy, jak też ich opiekunowie ze strony Kościoła. Jak łatwo zauważyć, jeśli nie wszystkie, to większość wspólnot posiadało odpowiedniego opiekuna kościelnego: promotora, ojca duchownego albo kapelana. Kolejnym dowodem wynikającym z dokonanej analizy przemawiającym za tym, że formy organizacyjne bractw były dobre i zapewniały poprawne ich funkcjonowanie, były liczba i kształt ich zarządów. Po pierwsze, w niektórych konfraterniach administracja posiadała w jakimś sensie charakter dwustopniowy. Występowały w nich bowiem dwie kategorie urzędników bractwa: starszych lub wyższych oraz oficjalistów młodszych albo niższych. Prawidłowością było posiadanie przez bractwa całej grupy urzędników, którzy mieli określone nazwy. Prawie do każdego przejawu działalności przypisany był odpowiedni urzędnik. A więc byli: radni, wizytatorzy, kontrolerzy, konsulatorzy, pisarze, szafarze, infirmarze, skarbnicy, jałmużnicy, chorążowie, stróże, słudzy braccy, itp.; można więc mówić o dużej specjalizacji urzędników. Powoływani byli również specjalni arbitrzy do rozsądzania sporów i nieporozumień między członkami. Powoływanie licznej grupy urzędników wraz ze szczegółowo określoną specyfikacją ich obowiązków, miało, o czym w niektórych bractwach jest wprost mowa, na celu i w założeniu dobre i poprawne funkcjonowanie bractw. Urzędnicy ci byli zwykle wybierani w czasie specjalnego zebrania przez głosowanie, co prawdopodobnie miało zapewniać powoływanie na urzędy osób dobrze przygotowanych, budzących zaufanie i dających gwarancję poprawnego wykonywania obowiązków. Pomijam tu pytanie, jak to wykonywanie przedstawiało się w praktyce, tym bardziej, że członkowie mieli wykonywać obowiązki dobrowolnie, nie były one nakazane pod grzechem. Rozliczanie z obowiązków stanowi oddzielną kwestię, której w swoich rozważaniach nie podejmowałem. Tutaj można jedynie domniemywać, że jeśli nie we wszystkich, to w większości bractw wszystko odbywało się poprawnie, zgodnie z założeniami. W tym celu byli powoływani owi wizytatorzy i kontrolerzy, mieli czuwać nad tym, aby do bractwa nie zakradły się jakieś nadużycia i nieprawidłowości. Być może, temu samemu celowi służyło częste zmienianie członków zarządu. W niektórych bractwach napominano nowo wybrany zarząd, aby czuwał nad sprawnym i poprawnym funkcjonowaniem wspólnoty. $Z$ reguły był on powoływany na rok czasu, do wyjątków należały dłuższe kadencje urzędów. Również przy wstąpieniu do bractwa przestrzegano pewnych form zewnętrznych, których nie będę tu opi- 
sywał, Co najwyżej, można jedynie zauważyć, że również na tym etapie bractwa prezentują się jako instytucje o dobrej organizacji. Wyrazem tego są księgi (katalogi) brackie, do których wpisywano nowo przyjętych członków. Prowadzenie ich należało do zadań jednego z urzędników, czyli do pisarza brackiego. Warto tu przypomnieć także, że w niektórych wspólnotach brackich działalność wewnętrzna i zewnętrzna podlegała kontroli ze strony wszystkich ich członków. Zapewne nie bez znaczenia dla struktury bractw i ich poprawnego funkcjonowania było też czytanie statutów brackich w czasie wspomnianych zebrań, zatrudnianie do pełnienia urzędów osób związanych z instytucjami administracji państwowej, a także związanymi z kościołem, czyli wywodzącymi się z grona służby kościelnej oraz podejmowanie się przez funkcjonariuszy brackich jednania i godzenia zwaśnionych parafian. Wszystkie one świadczą o tym, że bractwa cieszyły się wśród wiernych autorytetem, zbudowanym na strukturze wewnętrznej bractw i względnie dobrej znajomości podstaw prawnych.

Przytoczone przykłady struktury wewnętrznej wspólnot brackich wskazują, że była ona od strony organizacyjnej, jeśli nie wzorowa, to na pewno przemyślana i przeprowadzona $\mathrm{z}$ pełną świadomością. Stawia to bractwa $\mathrm{w}$ dobrym świetle, mimo tego, że były one organizacją bardzo powszechną oraz gromadziły licznie osoby o różnym statusie społecznym i zróżnicowanym poziomie edukacyjno-intelektualnym, były bowiem otwarte dla wszystkich chętnych do wstąpienia do nich. Może właśnie dlatego, poza względami dewocyjno-religijnymi nakazanymi i realizowanymi przez Kościól, były tak bardzo powszechne. To wszystko miało niewątpliwie wpływ na rolę, jaką bractwa, czy szerzej, stowarzyszenia religijne, odegrały w dziejach Kościoła, całych społeczeństw i społeczności lokalnych tamtych czasów. Jest to jednak inne zagadnienie, które wykracza poza ramy obecnych rozważań.

Słowa kluczowe: bractwo; konfraternia; struktura organizacyjna; zarząd

\section{BIBLIOGRAFIA}

\section{Żródla}

Bzowski, Różaniec Panny Maryjej teraz nowo w Krakowie Ś. Trójcy reformowany, cz. 4, Kraków 1600.

Kitowicz Jędrzej, Opis obyczajów za panowania Augusta III, oprac. Roman Pollak, wyd. 3, Wrocław 1970, s. 23.

Poniatowski Michał Jerzy, Ustanowienie bractwa miłosierdzia po parafiach dyecezyi płockiey, Warszawa 1777.

Poniatowski Michał Jerzy, Ustanowienie bractwa miłosierdzia po parafiach archidyecezyi gnieźnieńskiey, Łowicz 1786.

Statuty Bractwa Literackiego Nauki Chrześcijańskiej przy kolegiacie św. Małgorzaty w Nowym Sączu , wyd. Bolesław Kumor, „Archiwa, Biblioteki i Muzea Kościelne”, 2 (1961) z. 1-2, s. 357-370. 


\section{Opracowania}

Bielak Włodzimierz, Księga bractwa Trójcy Przenajświętszej w parafii Dywin 1763-1800, „Archiwa, Biblioteki i Muzea Kościelne”, 98 (2012) s. 5-18.

Czyż Joanna, Bractwa miłosierdzia w II połowie XVIII wieku w świetle statutów i wybranych źródeł, Lublin 1988 (mps, Archiwum KUL).

Encyklopedia wiedzy o jezuitach na ziemiach Polski i Litwy, oprac. Ludwik Grzebień, Kraków 1996, s. 62.

Flaga Jerzy, Arcybractwo Różańcowe przy kościele Franciszkanów-Reformatów we Włocławku, w: Non cesso gratias agere Deo et hominibus. Prace ofiarowane Ojcu dr Anzelmowi Januszowi Szteinke OFM z okazji Złotego Jubileuszu Kapłaństwa i ponad 50-lecia pracy historyczno-pisarskiej, red. Wacław Marian Michalczy OFM, Celestyn Mieczysław Paczkowski OFM, Kraków-Warszawa 2013, s. 488.

Flaga Jerzy, Bractwa religijne w Rzeczypospolitej w XVII i XVIII wieku, Lublin 2004.

Flaga Jerzy, Stowarzyszenia i bractwa religijne przy kościołach bernardyńskich do końca XVIII wieku, w: Pięćset pięćdziesiąt lat obecności OO. Bernardynów w Polsce (1453-2003), red. Wiesław F. Murawiec OFM, Damian A. Muskus OFM, Kalwaria Zebrzydowska 2006, s. 545-562.

Panek Bronisław, Dzieje bractwa Szkaplerza świętego przy kościele OO. Karmelitów w Krakowie na Piasku do końca XVII wieku, „Roczniki Teologiczno-Kanoniczne”, 10 (1963) z. 3, s. 50.

Pasternak Ferdynand, Historia kodyfikacji konstytucji zakonu paulinów od 1308 do 1930 r., „Nasza Przeszłość”, 31 (1969) s. 11-74.

Ruciński Henryk, Bractwo literackie w Koprzywnicy jako obraz struktury społecznej miasteczka w latach 1694-1795, „Przegląd Historyczny”, 65 (1974) z. 2, s. 270-272.

Ryk Maria Ksawera, Bractwo św. Urszuli w Krakowie, Lublin 1961, mps.

Wanat Józef Benignus, Zakon karmelitów bosych w Polsce. Klasztory karmelitów i karmelitanek bosych, Kraków 1979. 


\title{
RELIGIOUS FRATERNITIES IN THE OLD POLISH PERIOD IN THE LIGHT OF THEIR ORGANIZATION AND INTERNAL STRUCTURE
}

\begin{abstract}
Summary
The internal structure of the religious fraternities shows that it was, if not exemplary, certainly well thought out and carried out with full awareness. It reflects well on fraternities, even though they were very common organizations and had a large number of people with different social status as well as educational and intellectual levels, because they were open to all those willing to join them. Perhaps that is why, in addition to the devotional and religious reasons given by the Church, they were so commonplace. All of this undoubtedly affected the role that fraternities, or more broadly, religious associations played in the history of the Church, the entire societies and local communities of those times.
\end{abstract}

Keywords: fraternities; associations; organizational structure 